The University of Maine

\title{
DigitalCommons@UMaine
}

Earth Science Faculty Scholarship

Earth Sciences

6-1-1989

\section{Högbomite from the Aldan Shield, Eastern Siberia, USSR}

\author{
Edward S. Grew \\ University of Maine - Main, esgrew@maine.edu \\ Galina M. Drugova
}

N. V.Leskova

Follow this and additional works at: https://digitalcommons.library.umaine.edu/ers_facpub Part of the Earth Sciences Commons

\section{Repository Citation}

Grew, Edward S.; Drugova, Galina M.; and Leskova, N. V., "Högbomite from the Aldan Shield, Eastern Siberia, USSR" (1989). Earth Science Faculty Scholarship. 161.

https://digitalcommons.library.umaine.edu/ers_facpub/161 
Golyshev, S. I. , and Padalko, N. L. (1979) A theoretical study of oxygen-isotope distribution in oxides. Geochem. Int. 16, 157-60.

Harzer, D. (1970) Geochemical studies on hydrothermal minerals from deposits in the German Democratic Republic with the isotopes oxygen-18 and carbon13 (in German). Freiberg, Forschungsh. C, 247, 132 p.

Hattori, K, and Halas, S. (1982) Calculation of oxygen isotope fractionation between uranium dioxide, uranium trioxide and water. Geochim. Cosmochim. Acta, 46, 1863-8.

Jackson, N. J., and Rankin, A. H. (1976) Fluid inclusion studies at St Michael's Mount. Proc. Ussher Soc. 3, 430-4.

Kelly, W. C., and Rye, R. O. (1979) Geologic, fluid inclusion, and stable isotope studies of the tin-tungsten deposits of Panasqueira, Portugal. Econ. Geol. 74, 1721-822.

Kieffer, S. W. (1982) Thermodynamics and lattice vibrations of minerals: 5 . Applications to phase equilibria, isotopic fractionation, and high pressure thermodynamic properties. Rev. Geophys. Space Phys. 20, 827-49.

Matthews, A. (1973) Oxygen isotope geology: Experimental calibration of geothermometers with related experimental investigations. Unpubl. $\mathrm{PhD}$ thesis, Univ. of Manchester.

Matsuhisa, Y., Goldsmith, J. R., and Clayton, R. N. (1979) Oxygen isotope fractionation in the system quartz-albite-anorthite-water. Geochim. Cosmochim. Acta, 43, 1131-40.
Moore, F., and Moore, D. J. (1979) Fluid inclusion study of mineralization at St Michael's Mount, Cornwall, England. Trans. Instn Min. Metall. (B), 88, 5760.

Mu Zhigo et al. (1982) Oxygen, hydrogen and carbon isotope studies of Piaotang and Xihuashan quartz vein-type tungsten deposits, Jiangxi Province (in) Tungsten Geology symposium (Jiangxi, China, Oct. 1981), ESCAP/RMRDC (Bandung) and Geol. Publ. House (Beijing), 385-401.

O'Neil, J. R. (1986) Theoretical and experimental aspects of isotopic fractionation. In Stable isotopes (Valley, J. W., Taylor, H. P., and O'Neil, J. R., eds.) Reviews in Mineralogy, 16, Mineral. Soc. America, $1-40$.

Patterson, D. J., Ohmoto, H., and Solomon, M. (1981) Geologic setting and genesis of cassiterite-sulfide mineralization at Renison Bell, Western Tasmania. Econ. Geol. 76, 393-408.

Sun, S-S., and Eadington, P. J. (1987) Oxygen isotope evidence for the mixing of magmatic and meteoric waters during tin mineralization in the Mole Granite, New South Wales, Australia. Ibid. 83, 43-52.

Sushchevskaya, T. M., Ustinov, V. I., Nekrasov, I. A., Gavrilov, Y. Y., and Grinenko, V. A. (1986) The oxygen-isotope fractionation factor in cassiterite synthesis. Geochem. Int. 23, 57-60.

[Manuscript received 21 April 1988; revised 20 September 1988]

(C) Copyright the Mineralogical Society

KEYWORDS: oxygen isotopes, cassiterite, water, fractionation.

Department of Geology,

RHB New College,

Egham,

Surrey, TW200EX

\section{Högbomite from the Aldan Shield, Eastern Siberia, USSR}

Högвоміте, a complex oxide of $\mathrm{Al}, \mathrm{Fe}, \mathrm{Mg}$, and $\mathrm{Ti}$, is an important constitutent of some iron ores and emery deposits as well as an infrequent accessory in aluminous high-grade rocks (e.g. Grew et al., 1987). The recent increase in reports of new localities (e.g. Rammlmair et al., 1988) suggests that högbomite may be more widespread than is generally perceived. We report here högbomite from the Aldan Shield, Eastern Siberia. This högbomite is remarkable for the wide variation in composition measured in a single thin section. Our report is only the second from the USSR of högbomite for which chemical data are given. Reports of högbomite other than Moleva and Myasnikova's (1952) well-documented descrip- tion of högbomite from the Urals are based only on optical properties (Bobrovnik, 1955; Sinitsa, 1957; Sudovikov et al., 1962); the third citation includes mentions of högbomite in pelitic gneisses from unspecified localities in the Aldan Shield. In the present paper we present details of the paragenesis and chemistry of högbomite and several associated minerals; the reader is referred to Drugova et al. (in press) for a general account of the högbomite-bearing rock and its geological and geochemical significance.

Högbomite is found in a biotite-plagioclasecorundum-spinel schist cropping out $2 \mathrm{~km}$ east of the Aldan River at a point $1 \mathrm{~km}$ north of its tributary Ayyannaakh Creek (approximately $120 \mathrm{~km}$ 
southwest of the city of Aldan). The högbomitebearing rock is part of a metasedimentary unit consisting largely of quartzite with layers of pelitic gneisses and schists; associated rocks include orthopyroxene-bearing plagiogneiss. These rocks were metamorphosed in the granulite facies, subsequently migmatized during two events in the amphibolite facies, and intruded by microcline granite (Drugova et al., in press).

The högbomite-bearing rock is a biotiteplagioclase schist containing well-aligned cylindrical nodules of corundum, magnetite, and spinel up to $10 \mathrm{~cm}$ long and $6 \mathrm{~cm}$ across as well as disseminated grains of corundum, magnetite, rutile(?) and högbomite. The oxide nodules constitute up to 30 or $40 \%$ of the rock and are found over an area of 20 or $30 \mathrm{~m}^{2}$ in outcrop. The matrix to the nodules is a medium-grained rock (mostly $0.5-$ $3 \mathrm{~mm}$ ) consisting of dark biotite, plagioclase, subordinate magnetite, rare clinozoisite, and minor secondary muscovite. The plagioclase (An $40-46$ in the section analysed with the microprobe, Drugova et al., in press) is locally zoned. The nodules generally have a core of corundum up to $12 \mathrm{~mm}$ across, surrounded by a mantle of spinel, magnetite, and corundum. Adjacent to the corundum core is an inner rim of magnetite. Spinel is commonly dominant in the remainder of the mantle; magnetite, rarely in association with ilmenite, occurs as isolated grains. The spinel also contains abundant blebs of exsolved magnetite in distinct planar arrays. Towards the margin of the mantle are biotite and patches of corundum riddled with magnetite. This corundum is in places dichroic in blue. In the analysed section, the oxide nodule has a corona of fine-grained pale biotite. Discrete biotite flakes near this corona are in places pale brown or green. Other minerals in the nodule-bearing rocks are apatite, zircon, allanite, monazite, pyrrhotite, and rutile (Drugova et al., in press); of these, only zircon was found in the analysed section.

Högbomite is found in both the matrix and in the nodules; its distribution is irregular. Grains are mostly 0.05 to $0.2 \mathrm{~mm}$ across, locally up to $0.35 \mathrm{~mm}$, and range from nearly equant to planar. In the matrix, högbomite is closely associated with magnetite and forms aggregates contiguous to irregular magnetite grains; in some cases, högbomite appears to have replaced magnetite; in others, textural relations are ambiguous. Near some högbomite, magnetite appears to be replaced by a fine-grained mineral resembling rutile (leucoxene?). In the nodules, högbomite occurs mostly in and near spinel and locally with magnetite or corundum and, in places, touches biotite. Högbomite is moderate brown (nodule) to dark brown (matrix) and is dichroic.

One grain of the nodule högbomite and three grains (in two aggregates) of the matrix högbomite, together with spinel (in two spots) and associated minerals, were analysed in a single thin section within a $1 \times 1.5 \mathrm{~cm}$ area with a Cameca 'Camebax-micro' electron microprobe at the Institute of Geology, Yakutsk (selected analyses listed Table 1). The nodule and matrix högbomite differ most in $\mathrm{Ti}$, total $\mathrm{Fe}$, and $\mathrm{Mg}$. Matrix högbomites also vary in composition from grain to grain and within a grain (e.g. $\mathrm{TiO}_{2}, 4.6-5.6 \% ; \mathrm{ZnO}$, $0.8-1.8 \%$ ), and the nodule högbomite grain also appears to be zoned in Ti. In formulae recalculated assuming 22 cations, 30 oxygens and 2 hydroxyls (Gatehouse and Grey, 1982; Grew et al., 1987), most of the $\mathrm{Fe}$ in the matrix högbomite is $\mathrm{Fe}^{2+}$ and that in the nodule högbomite, $\mathrm{Fe}^{3+}$, and the two compositions can be related by the substitutions $\mathrm{Ti}+\mathrm{Fe}^{2+}=2 \mathrm{Fe}^{3+}\left(\mathrm{TiFe}_{-1}\right.$, ilmenite-hematite type) and $\mathrm{Mg}=\mathrm{Fe}\left(\mathrm{MgFe}_{-1}\right) ; \mathrm{Al}$ contents in the formulae are nearly identical. However, these formulae were calculated assuming the $8 H$ polytype, apparently a rare polytype (Beukes et al., 1986), and thus may not be valid for either or both of the Aldan högbomites. Indeed, the excessively high analytical totals calculated for the nodule högbomites (e.g. 102.4\%, Table 1) indicate that this calculation results in an excessive estimate of $\mathrm{Fe}^{3+}$ content. On the other hand, the Zakrzewski (1977) formula for recasting högbomite analyses yields $\mathrm{Fe}^{3+} /$ Total $\mathrm{Fe}$ ratios of 0.07 and 0.08 for the matrix högbomite and $<0$ and 0.05 for the nodule högbomite. These values seem too low, because the corresponding ratios in spinel are calculated to be 0.10 to 0.13 . In the absence of detailed crystallographic studies of different högbomite polytypes, it is not possible to reliably recast analyses and estimate $\mathrm{Fe}^{3+} / \mathrm{Fe}^{2+}$ ratios, nor is it possible to determine water contents. We have calculated a value of $\mathrm{H}_{2} \mathrm{O}$ using the Gatehouse and Grey (1982) formula in order to call attention to this potentially critical component of högbomite.

Magnetite (5 analyses) in the matrix and nodules contain $0.2-0.3 \% \quad \mathrm{Cr}_{2} \mathrm{O}_{3}$ and $0-0.2 \%$ $\mathrm{TiO}_{2}, \mathrm{Al}_{2} \mathrm{O}_{3}, \mathrm{MnO}, \mathrm{MgO}$, and $\mathrm{ZnO}$ (for example, Table 1), with the exception of one spot with $3.1 \%$ $\mathrm{Al}_{2} \mathrm{O}_{3}$ in the matrix. The averaged spinel analyses in Table 1 are representative of the 4 analyses in $\mathrm{Cr}_{2} \mathrm{O}_{3}$ contents $(0.08-0.12 \%)$ and $X(\mathrm{Fe}) T(0.35-0.36)$, while $\mathrm{ZnO}$ in the unlisted analyses reaches $1.68 \%$. Corundum (4 analyses) in the spinel mantle contains $0.37-0.99 \% \mathrm{Fe}_{2} \mathrm{O}_{3}$ and $0.18-0.24 \% \mathrm{Cr}_{2} \mathrm{O}_{3}$. The dark biotites of the matrix (4 flakes analysed; average of 2 in Table 1) are titanian $\left(2.8-3.1 \% \mathrm{TiO}_{2}\right)$, and relatively 
Table 1. Composition of Minerals in Sample 02068 Ayyanaakh Stread. Aldan Shield, USSR

\begin{tabular}{|c|c|c|c|c|c|c|c|c|c|c|}
\hline & & Biotite & & & Högbomit & & spinel & Mag & ite & Corundu \\
\hline & Ma $=r i x$ & $\operatorname{Cor}$ & rons & Matr & & Nodule & Nodule & Nodule & Matrix & Nodule \\
\hline $\begin{array}{l}\text { Natioer } \\
\text { of } \\
\text { Analyses }\end{array}$ & 25 & 1 & 1 & 1 & $I$ & 2 & 2 & 1 & 1 & 1 \\
\hline $\mathrm{SiO}_{2}$ & 35.82 & 37.16 & 38.48 & 0.0 & 0.05 & 0.01 & 0.0 & 0.0 & 0.0 & 0.0 \\
\hline $\mathrm{FiO}_{2}$ & 3.12 & 0.38 & 0.24 & 5.30 & 5.55 & 2.95 & 0.0 & 0.0 & 0.0 & 0.0 \\
\hline $\mathrm{Al}_{2} \mathrm{O}_{3}$ & 17.57 & 21.52 & 19.10 & 61.20 & 60.74 & 64.67 & 65.40 & 0.21 & 0.15 & 99.04 \\
\hline $\mathrm{Cr}_{2} \mathrm{O}_{3}$ & 0.06 & 0.07 & 0.06 & 0.25 & 0.20 & 0.17 & 0.10 & 0.18 & 0.29 & 0.19 \\
\hline$F \in 0^{1}$ & 13.54 & 7.22 & 7.43 & 24.26 & 25.30 & $17 \cdot 10$ & 17.29 & 87.88 & 87.74 & 0.99 \\
\hline MnO & 0.11 & 0.12 & 0.08 & 0.25 & 0.34 & 0.27 & 0.39 & 0.0 & 0.03 & 0.01 \\
\hline $\mathrm{MgO}$ & 13.65 & 19.43 & 20.48 & 5.97 & 5.47 & 13.14 & 17.57 & 0.0 & 0.0 & 0.01 \\
\hline $2 n o$ & - & - & - & 1.35 & 0.83 & 0.94 & 0.63 & 0.15 & 0.03 & - \\
\hline $\mathrm{CaO}_{\mathrm{a}}$ & 0.0 & 0.03 & 0.02 & 0.0 & 0.01 & 0.0 & 0.0 & 0.0 & 0.0 & 0.02 \\
\hline $\mathrm{Na}_{2} \mathrm{O}$ & 0.15 & 0.26 & 0.13 & 0.07 & 0.02 & 0.02 & 0.03 & 0.08 & 0.0 & 0.0 \\
\hline $\mathrm{K}_{2} \mathrm{O}$ & 10.36 & 10.30 & 10.04 & 0.0 & 0.05 & 0.0 & 0.0 & 0.02 & 0.0 & 0.0 \\
\hline $\mathrm{H}_{2} \mathrm{O}^{2}$ & 3.98 & 4.22 & 4.21 & 1.45 & 1.45 & 1.55 & - & - & - & - \\
\hline Total & 98.36 & 100.61 & 100.27 & $100 \cdot 10^{3}$ & $100.01^{4}$ & $100.82^{5}$ & $101.41^{6}$ & $88.52^{7}$ & $88.24^{8}$ & 100.26 \\
\hline & & & & & & & oxmu1ae & & & \\
\hline Oxygens & 22 & 22 & 22 & 31 & 31 & 31 & 4 & 4 & 4 & 3 \\
\hline $\mathrm{si}$ & 5.398 & 5.278 & 5.478 & 0.0 & - & - & 0.0 & 0.0 & 0.0 & 0.0 \\
\hline$A 1^{I V}$ & 2.602 & 2.722 & 2.522 & - & - & - & - & - & -- & -- \\
\hline A 1 & - & - & $\cdots$ & 14.871 & 14.839 & 14.790 & 1.950 & 0.010 & 0.007 & 1.985 \\
\hline$A 1^{V I}$ & 0.518 & 0.880 & 0.683 & - & - & - & - & - & $m$ & - \\
\hline $\mathrm{Cr}_{\mathrm{r}}$ & 0.007 & 0.008 & 0.007 & 0.041 & 0.033 & 0.026 & 0.002 & 0.006 & 0.009 & 0.003 \\
\hline $\mathrm{T} \mathbf{i}$ & 0.354 & 0.041 & 0.026 & 0.822 & 0.865 & 0.430 & 0.0 & 0.0 & 0.0 & 0.0 \\
\hline $\mathrm{Fe}^{2+}$ & 1.706 & 0.858 & 0.885 & 2.738 & 2.988 & 0.452 & 0.317 & 0.996 & 0.998 & -- \\
\hline $\mathrm{Fe}^{3+}$ & - & - & - & 1.445 & 1.398 & 2.323 & 0.048 & 1.984 & 1.983 & 0.013 \\
\hline Mn & 0.014 & 0.014 & 0.010 & 0.044 & 0.060 & 0.044 & 0.008 & 0.000 & 0.001 & 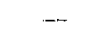 \\
\hline $\mathrm{Mg}_{\mathrm{g}}$ & 3.067 & 4.114 & 4.346 & 1.835 & 1.690 & 3.800 & 0.663 & 0.000 & 0.000 & $\ldots$ \\
\hline Tota 1 & 5.666 & 5.915 & 5.957 & - & - & - & - & - & -- & -- \\
\hline $\mathrm{Ca}$ & 0.0 & 0.005 & 0.004 & - & - & - & - & - & - & - \\
\hline $\mathrm{Na}$ & 0.045 & 0.044 & 0.036 & - & - & - & - & - & 0.0 & - \\
\hline K & 1.991 & 1.866 & 1.823 & - & - & - & - & - & 0.0 & - \\
\hline Total & 2.036 & 1.915 & 1.863 & - & - & - & - & - & -- & 0.0 \\
\hline $2 n$ & - & - & - & 0.206 & 0.127 & 0.134 & 0.012 & 0.004 & 0.001 & - \\
\hline Total & 15.702 & 15.830 & 15.820 & 22.002 & 22.000 & 21.999 & 3.0 & 3.000 & 2.999 & 2.001 \\
\hline $\mathrm{X}(\mathrm{Fe}) \mathrm{T}^{9}$ & 0.36 & 0.17 & 0.17 & 0.70 & 0.72 & 0.42 & 0.36 & - & -- & - \\
\hline
\end{tabular}

Notes.

Dash - Not analysed or not calculated.

1. All Ee as $F e 0$, except for corunduri, for which all Fe as $F_{2} 0_{3}$. In formulae. Fe and Fe calculated froth stoichionetry,

2. Calculated assuming ideal hydroxyl contents for hbgbonite (2(OH) and 22 cations, Gatehouse and Grey. 1982$)$ athd fox biotite.

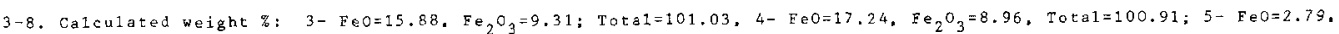
$\mathrm{Fe}_{2} \mathrm{O}_{3}=15.91$. Tota $1=102.42 ; 6-\mathrm{EeO}=15.00 . \mathrm{Fe}_{2} \mathrm{O}_{3}=2.54$, Total=101.66; 7-FeO $=29.36, \mathrm{Fe}_{2} 0_{3}=65.04$. Total $=95.04 ; 8-$ $\mathrm{FeO}=29.37, \mathrm{Fe}_{2} \mathrm{O}_{3}=64.87, \mathrm{Tota}=94.74$.

9. $\mathrm{X}(\mathrm{Fe}) \mathrm{T}=\operatorname{total} \mathrm{F} e /(\mathrm{Mg}+\mathrm{Totat} \mathrm{Fe})$

Microprobe Operating Condicions: $20 \mathrm{kV}, 40 \mathrm{nA}$. 
iron rich $\left(X_{\mathrm{Fe}}=0.35-0.37\right)$, while the fine-grained biotites in the corona ( 7 analyses) are almost free of $\mathrm{Ti}\left(0-0.4 \% \mathrm{TiO}_{2}\right)$, aluminous $\left(19-23 \% \mathrm{Al}_{2} \mathrm{O}_{3}\right)$ and magnesian $\left(X_{\mathrm{Fe}}=0.15-0.17\right)$.

The present mineralogy and chemistry of the högbomite-bearing rocks is due to a complex metamorphic history to which Drugova et al. (in press) assigned 3 stages. The $X_{\mathrm{Fe}}$ 's of the matrix biotite, which is interpreted to have formed during the granulite-facies event, and spinel are approximately equal, that is $K_{D}=[\mathrm{Fe} / \mathrm{Mg}(\mathrm{Sp} 1)] /[\mathrm{Fe} /$ $\mathrm{Mg}(\mathrm{Bt})]=0.91-1.00$, in marked contrast to equilibrium spinel-biotite pairs, for which $K_{D} \geqslant 3.7$ (Lal et al., 1978; Waters and Moore, 1985). Consequently, the analysed spinel probably did not equilibrate with the matrix biotite, whose rather constant composition from grain to grain is presumed to be little changed since original crystallization in the granulite facies. The spinelmagnetite-corundum intergrowths in the mantles of the nodules could have resulted from exsolution, breakdown, and possibly oxidation of a homogeneous hercynite-rich member of the spinel group that had equilibrated with the matrix biotite. Högbomite in the nodule probably formed during this breakdown, drawing on $\mathrm{Ti}$ and $\mathrm{Zn}$ in the original homogeneous spinel. By analogy with other högbomite occurrences (e.g. Grew et al., 1987), appearance of högbomite suggests interaction of the secondary spinel, magnetite, and corundum with hydrous fluids. Alternatively $\mathrm{Ti}$ for högbomite could have originated from the matrix biotite, which released $\mathrm{Ti}$, its remaining constituents forming the corona biotite. The $K_{D}(\mathrm{Mg}-\mathrm{Fe})$ of $2.5-3.1$ for spinel and corona biotite is closer to the presumably equilibrium values cited above. Thus högbomite formation in the nodules, breakdown of a hercynite-rich phase into spinel, magnetite, and corundum, and crystallization of corona biotite could be coeval and closely related to either intrusion of microcline granite or retrogression in the amphibolite facies.

The matrix högbomite is presumed to have formed coevally with the nodule högbomite and could have formed from magnetite, but there is no obvious source of Al. Alternatively the present magnetite-högbomite \pm rutile (?) aggregates

KEYword s: högbomite, Aldan Shield, Siberia, USSR. could have resulted from the recrystallization (and oxidation?) of a pre-existing $\mathrm{Fe}-\mathrm{Mg}-\mathrm{Ti}-$ $\mathrm{Al} \pm \mathrm{Zn}$ spinel phase (+ ilmenite?). In any case, given its different composition, the matrix högbomite must have formed from a different mix of oxide phases from those in the nodule, thereby implying that compositional factors, including oxygen fugacity, rather than pressure and temperature, are the main controls on högbomite chemistry.

This research was carried out with the support of the interacademy exchange program between the USSR and USA within the framework of IGCP Project 235 'Metamorphism and Geodynamics'.

\section{References}

Beukes, G. J., van Zyl, V. C., Schoch, A. E., De Bruiyn, H., van Aswegen, G., and Strydom, D. (1986) Neues Jahrb. Mineral. Abh. 155, 53-66.

Bobrovnik, D. P. (1955) In Voprosy mineralogii osadochnykh obrazovaniy, Kniga 2-ya [Problems of mineralogy of sedimentary formations, Book 2], L'vovskiy Gosud. Univ. im. Ivana Franko, 215-16.

Drugova, G. M., Grew, E. S., and Leskova, N. V. Zap. Vses. mineral. Obshch. (in press).

Gatehouse, B. M., and Grey, I.E. (1982) Am. Mineral. 67, 373-80.

Grew, E. S., Abraham, K., and Medenbach, O. (1987) Contrib. Mineral. Petrol. 95, 21-31.

Lal, R. K., Ackermand, D., Seifert, F., and Haldar, S. K. (1978) Ibid. 67, 169-87.

Moleva, V. A., and Myasnikov, V. S. (1952) Dokl. Akad. Nauk SSSR, 53, 733-36.

Rammlmair, D., Mogessie, A., Purtscheller, F., and Tessadri, R. (1988) Am. Mineral. 73, 651-6.

Sinitsa, S. (1957) Mineral. Sbornik L'vovsk. Geol. Obshch. 11, 170-86.

Sudovikov, N. G., Drugova, G. M., Krylova, M. D., and Mikhaylov, D. A. (1962) In Petrografia Vostochnoy Sibiri [Petrography of Eastern Siberia], vol. 2, Moscow, Acad. Sci. Publishing House, 320-446.

Waters, D. J., and Moore, J. M. (1985) Contrib. Mineral. Petrol. 91, 369-82.

Zakrzewski, M. A. (1977) Neues Jahrb. Mineral. Mh., 373-80.

[Manuscript received 29 June 1988;

revised 10 October 1988]

(C) Copyright the Mineralogical Society

Department of Geological Sciences, University of Maine, Orono, ME 04469, USA EdWARD S. GREW

Institute of Geology and Geochronology of the Precambrian, Academy of Sciences of the USSR, Leningrad, USSR 199164 Galina M. Drugova

Institute of Geology, Yakutsk Filial, Siberian Division, Academy of Sciences of the USSR, Yakutsk, USSR 